\title{
МЕДІАЦІЇ ЯК СПОСІБ ПРОФІЛАКТИКИ КОНФЛІКТІВ У СФЕРІ ДЕРЖАВНОГО УПРАВЛІННЯ
}

Волошин В. $\boldsymbol{\Gamma}$., канд. наук з держ. упр., провідний фахівець відділу організаційно-адміністративного забезпечення Центру оцінювання кандидатів на зайняття посад державної служби Української школи урядування, м. Київ, Україна.

Mycmaфaєва Уpiє C., канд. наук 3 держ. упр., провідний фахівець відділу тестології і експертного оцінювання Центру оцінювання кандидатів на зайняття посад державної служби Української школи урядування, м. Київ, Україна.

У статті подано аналіз сочіальної та правової природи медіаизї та можливостей медіації, як способу запобігання, вирішення спорів (конфліктів) в системі державного управління. Доводиться, що украӥнська держава усвідомлює роль медіації у виріменні соціально значущих завдань. Суттю медіації як соціального явища, є те щзо изей метод орієнтований на розв'язання спорів у позасудовому порядку, на досягнення консенсусу, згоди різних суперечливих поглядів, позицій, вирішення спірних ситуацій. Позитивним є той факт, щуо ией інструмент, як альтернативний спосіб превентивної профілактики запобігання спорам (конфліктам), иляхом врахування інтересів кожної сторони та досягненням компромісного рішення є затребуваним в суспільстві.

Аналіз законодавства показав, щуо на шляху запровадження практики медіації вже зроблено чималі кроки, але цзього недостатньо. Необхідно прийняти спеціальний закон про медіацію, та внести зміни до законодавства. Прийняття закону сприятиме професійної організації та введення в широку практику на всіх рівнях влади та громадянського суспільства інституту медіації,яке стане до- 
датковим механізмом вирішення спорів, налагодження комунікаиіі та пошуку компромісних і спільно вироблених консенсусних рішень між органами влади і суспільством.

Використання медіації в системі державного управління дозволить: узгодити інтереси та дотриматися балансу інтересів у будь-якій сфері суспільних відносин; посилить організачійний потенціал суб 'єктів управління; зміцніть координацію дій $і$ зближення стратегій наявних інститутів державної влади та управління; підвищить соиіальну стабільність в суспільстві та знизять конфліктогенність в сочіуме; забезпечить збалансованість державноуправлінських відносин тощо.

Якщу говорити про перспективи подальших розвідок, то на наш погляд вони повинні стосуватися вивчення можливостей застосування медіації в самих різних сферах діяльності і суспільного життя, в тому числі вивчення можливостей застосування медіації як альтернативного способу запобігання спорам (конфліктам) в прочесах владно-управлінської діяльності.

Ключові слова: державне управління, конфлікт, медіачія, державний службовецьь.

Постановка проблеми у загальному вигляді. Визначальною i необхідною умовою суспільно-політичного i соціальноекономічного розвитку держави є проведення більш інтенсивних реформ в системі державного управління. Незважаючи на певні успіхи на ниві реформування, цей процес не $\epsilon$ стійким,так як наштовхується на проблему дисбалансу політичних інтересів, сил та груп впливу, а також відсутність налагодженого діалогу влади 3 інституціями сучасного громадянського суспільства. Це в свою чергу породжує конфліктні та кризові явища у політичній, економічній, соціально-побутовій сферах життя суспільства.

Наслідком цього $є$ те, що процеси реформування просуваються набагато повільніше ніж це необхідно, а сама система державного управління починає функціонувати неефективно.

Потенційно конфлікти в організаціях системи державного 
управління - $\epsilon$ результатом розвитку взаємодії між окремими iii структурними елементами, якими можуть бути окремі службовці, iii структурні підрозділи чи організація загалом, а також результатом iii взаємовідносин із зовнішніми агентами - громадянами, підприємствами, установами, організаціями» [12].

Цілком очевидно, що ігнорування таких проблемних питань як протистояння i неузгодженостей між суб'єктами публічноуправлінської діяльності,нерозуміння населенням суті та необхідностізмін,несприйняття нимипроведених реформ, наявності корупції в системі державного управління, невирішених політичних конфліктів, невисоким ступенем віри людей в здатність держави захистити їх від злочинностіпризводять досоціального напруження в суспільстві, зіткненню людей.

3 огляду на це, особливої ваги набуває потреба в застосуванні медіації як дієвого способу конструктивних взаємовідносин у системі державного управління з метою профілактики помилкових непорозумінь і конфліктів.

Аналіз останніх досліджень і публікацій. Окремі аспекти застосування альтернативних методів вирішення спорів (конфліктів),заснованих на медіації висвітлені в працях вітчизняних і зарубіжних науковців.

Зокрема, до визначення поняття медіації, іiї відмінних ознак присвячені праці, М. Поліщук, Ю. Притика, О. Бєлінської, В. Рєзникова та інші.

Питання правової природи медіації, іiї різних аспектів та сфер застосування дослідженні в працях: О. Сидєльнікова «нститут примирення сторін в адміністративному судочинстві», Н. Боженко «Адміністративно-правове забезпечення медіації як способу вирішення адміністративних спорів», Т. Шинкар «Застосування медіації в адміністративному судочинстві: вітчизняний та зарубіжний досвід» та А. Бортнікової «Правові засади застосування медіації як способу вирішення публічно-правових спорів».

Особливу увагу привертають праці 3. Красиловської [17] та Є. Бородіна [3], які присвячені дослідженню інституту медіації як способу вирішення проблем в системі публічного управління 
України та організаційно-правовім підставам застосування медіації в системі державного управління.

Огляд досліджень феномена медіації свідчить про те, що більшість 3 них зосереджені на правових та психологічних аспектах цього явища,проте в них не розглянуті саме процес інтеграції методу в повсякденну практику системи державного управління, який був би спрямований не стільки на врегулювання конкретних конфліктів, скільки на їх запобігання, на навчання державних службовців навичкам вирішення спорів (конфліктів) у професійній сфері шляхом активних переговорів,та на вихованні їх правосвідомості.

Формулювання цілей статті (постановка завдання). Мета статті - аналіз соціальної та правової природи медіації та можливостей медіації, як способу запобігання, вирішення спорів (конфліктів) в системі державного управління.

Виклад основного матеріалу дослідження. Відповідно до Конституції України, по перше «Права і свободи людини та їх гарантії визначають зміст і спрямованість діяльності держави» (ст. 3); nо-друге, «Держава відповідає перед людиною за свою діяльність. Утвердження і забезпечення прав і свобод людини є головним обов'язком держави» (ч. 2 ст. 3); no-третє, «Органи державної влади та органи місцевого самоврядування, їх посадові особи зобов'язані діяти лише на підставі, в межах повноважень та у спосіб, що передбачені Конституцією та законами України» (ч. 2 ст. 19).

Закріпивши в Конституції норми про права і свободи людини держава взяла на себе обов'язок щодо їх забезпечення в процесі управлінської діяльності. В цьому і проявляється одна з основних задач держави - гарантії права і свободи людини. Поряд 3 цим пріоритетною функцією держави $є$ забезпечення та реалізація принципу верховенства права у суспільстві, де кожен має право на справедливий розгляд та урегулювання спірних (конфліктних) ситуацій.

Виконання цих функцій здійснюється державою в рамках визначених Конституцією та законами України через органи державної влади, органи місцевого самоврядування їхніх посадових та службових осіб, які повинні додержуватися юридичної рівності 
усіх перед законом, спрямовувати свою діяльність на досягнення ідеалів справедливості, тазабезпечувати права і свободи людини.

Зміст цих статей ілюструє,щовсі вони передбачають пріоритет прав i свобод людини та громадянина. Більш того принцип верховенства права передбачає взаємну відповідальність людини та держави.

Процес державного управління характеризується формуванням державно-управлінських відносин, які мають свої ознаки, а саме: інтереси, потреби, права й обов'язки учасників цих відносин, що пов'язані з виконавчою та розпорядчою діяльністю держави, 3 державним управлінням, виконавчою владою та місцевим управлінням; однією з сторін у цих відносинах завжди виступає суб'єкт 3 владними повноваженнями (орган виконавчої влади, посадова особа, службовці, що наділені державно-владними повноваженнями та інші) [20, с. 120-121].

При виконанні органами влади управлінських функцій щодо реалізації прав, свобод та інтересів, повноважень у публічноправових відносинах, а також при наданні адміністративних послуг та пов'язаних з ним прав, свобод та інтересів можуть виникати протиріччя що передує виникненню спору (конфлікту) [21, с. 102].

Також підставою до виникнення публічно-правового спору (конфлікту) можуть бути прийняті рішення (нормативно-правові акти чи індивідуальні акти), дії чи бездіяльність суб' єктів публічноправових відносин, які порушують права, свободи та інтереси інших суб' єктів публічно-правових відносин [4].

Наслідком цього, може бути виникнення різноманітних непорозумінь, неузгодженостей, конфліктних ситуацій,в процесі державно-управлінської діяльності. Така ситуація виникає, як з вини службовців, так і через незалежні від них обставини, але негативні наслідки яких вони зобов'язані усунути, щоб знизити соціальне напруження, його ескалацію та загострення.

В більшості випадків вирішення такого спору відбувається в судовому порядку і прийняте судове рішення, має відкритий характер та підлягає оприлюдненню в електронній формі, або може публікуватися у друкованих виданнях [25]. 
Все це в цілому не поліпшує імідж держави і не відповідає очікуванням громадськості та не підвищує довіру суспільства до органів державної влади.

У специфічній професійній діяльності державних службовців, також закладено конфліктний потенціал, який створюється з одного боку під впливом факторів зовнішнього середовища (функціонування суб'єктів правовідносин), а з іншого боку, внутрішнім середовищем (створюваної сферою адміністративно-службових і соціальнопрофесійних відносин). Це може призвести до виникнення протиріч між приватним інтересом державного службовця i правами i законними інтересами громадян, організацій, суспільства або держави,і тим самим сприяє виникненню, формуванню, розвитку і протіканню конфліктів в державно-адміністративній сфері. Що в кінцевому підсумку завдає шкоди правам і законним інтересам громадян, організацій, суспільства або держави.

Відповідно до Закону України «Про запобігання корупції» під приватним інтересом службовця, яка впливає або може вплинути на об'єктивне виконання службових обов'язків розуміється будь-який майновий чи немайновий інтерес особи, у тому числі зумовлений особистими, сімейними, дружніми чи іншими позаслужбовими стосунками з фізичними чи юридичними особами, у тому числі ті, що виникають у зв'язку з членством або діяльністю в громадських, політичних, релігійних чи інших організаціях, зазначено у частини 1 статті 1 цього Закону.

У разі виникнення у службовця приватного інтересу, яка призводить або може привести до реального конфлікту інтересів, службовець зобов'язаний повідомити про це не пізніше наступного робочого дня з моменту, коли він дізнався чи повинен був дізнатися про наявність у нього реального чи потенційного конфлікту інтересів безпосереднього керівника, а у випадку перебування особи на посаді, яка не передбачає наявності у неї безпосереднього керівника, або в колегіальному органі - Національне агентство чи інший визначений законом орган або колегіальний орган, під час виконання повноважень у якому виник конфлікт інтересів, відповідно (ч.1 п.2 статті 28 Закону «Про запобігання корупції»); 
відповідно до частині першій статті 65 Закону, за порушення вимог щодо запобігання та врегулювання конфлікту інтересів службовець несе дисциплінарну відповідальність (ч.2 статті 65 Закону); цивільно-правову відповідальність (відшкодування матеріальної та / або моральної шкоди відповідно до Цивільного кодексу України, статті 22; 23); адміністративну відповідальність (ст. 14 КпАП України).

У цьому контексті застосування процедури медіації, як превентивного заходу запобігання конфлікту інтересів в разі виникнення конфліктної ситуації, коли причиною $є$ виникнення у державного службовця приватного інтересу, яке з годом може привести до потенційного або до реального конфлікту інтересівбуло б своєчасно.

Діяльність органів державної влади в основному базується на використанні імперативних методів правового регулювання, які побудовані на засадах субординації учасників правовідносин. В той же час гармонійний розвиток суспільства можливий тільки при узгодженні інтересів різних його членів, тому діяльність органів державної влади повинна бути спрямована на забезпечення реалізації цих прав, свобод та інтересів громадян.

Разом 3 цим завданням органів державної влади у процесі реалізації цих прав, свобод та інтересів максимально пом'якшити зіткнення приватних інтересів різних учасників правовідносин i правовими засобами сприяти компромісному зближенню публічного і приватних інтересів.

На це вказує і В. Кафарський, «одним із пріоритетів та завдань діяльності держави та місцевого самоврядування $є$ досягнення компромісу між органом публічної адміністрації та громадянином» [11, C. 152-165].

Поміж іншого, впровадження концепції належного урядування включає механізми, процеси та структури, за допомогою яких органи влади, громадяни та соціальні групи координують свої інтереси, використовують права та виконують обов'язки, а також виступають посередниками у вирішенні проблемних питань розвитку суспільства [13]. 
Загалом, всі ці процеси передбачають у своєму змісті процедуру медіації, пояснюється це тим, що в суспільстві є декілька суб’єктів (акторів) і відповідна кількість точок зору. Належне урядування потребує медіації різних інтересів у суспільстві для досягнення загального консенсусу щодо взаємовигідного інтересу всієї спільноти та засобів його досягнення [40].

В той же час, процедура медіації розвиває суспільство, вчить вести діалог, відстоювати свої інтереси, враховуючи при цьому думку інших громадян, поважати їх права, позицію, що в кінцевому рахунку сприяє зміцненню правопорядку і формування правової держави [10, с.116].

Отже, для того щоб знизити градус протистояння між різними гілками влади, між суб' єктами владних повноважень та суспільством, щоб забезпечити врегулювання суперечок між конфліктуючими сторонами доцільно впроваджувати і поширювати альтернативні способи вирішення конфліктів, зокрема медіацію.

Що ж мається на увазі під поняттям медіація (посередництво)? Медіація є одним із видів посередництва. 3 анг. mediation посередництво, mediator - посередник, примиритель; mediatory - посередницький - вид альтернативного врегулювання спорів, метод вирішення спорів із залученням посередника (медіатора), який допомагає сторонам конфлікту налагодити процес комунікації і проаналізувати конфліктну ситуацію таким чином, щоб вони самі змогли обрати той варіант рішення, який би задовольняв інтересі і потреби всіх учасників конфлікту [39].

Медіація входить до пакету методів позасудового неформального врегулювання спорів, які отримали назву «альтернативне вирішення спорів», або АВС (в англомовній літературі-ADR (Alternative Dispute Resolution). AВС визначають як групу процесів, за допомогою яких вирішуються спори, конфлікти і справи без звернення до судових розглядів [34, с. 10].

Посередництво - це процес, у якому «третя сторона» (посередник) допомагає сторонам спірної (конфліктної) ситуації провести переговори, спрямовані на досягнення взаємоприйнятного рішення [7]. 
Медіація $є$ універсальним способом вирішення правових конфліктів, який динамічне розвивається і відповідає викликам сучасного світу [38].

Отже, сутність медіації полягає у тому, що цей спосіб дозволяє вийти за рамки визначеного спору і виявити справжні причини конфлікту, при цьому виробити спільне рішення по його вирішенню і врегулюванню, тим самим задовольнивши істинні інтересі сторін конфлікту.

В українському законодавстві вже закладено підвалини національного бачення процедури медіації, які відображені в низці законодавчих актів. А саме:

у ч. 1 та ч. 5 ст. 55 Конституції України проголошено, що кожному гарантується право на оскарження в суді рішень, дій чи бездіяльності органів державної влади, органів місцевого самоврядування, посадових і службових осіб та кожен має право будь-якими не забороненими засобами захищати свої права і свободи від порушень і протиправних посягань. Ця стаття передбачає механізм становлення медіації, як способу вирішення публічноправового спору в соціально-правової системі нашої держави.

у ч. 4 ст. 124 Конституції України, закріплює припис про те, що «законом може бути визначений обов'язковий досудовий порядок урегулювання спору» [14]. Це положення вказує та те, що досудове врегулювання спорів за згодою сторін 3 використанням альтернативних методів, зокрема медіації є правомірним.

Невід'ємним конституційним правом кожної людини є право на захист своїх прав.Механізм реалізаціїцього права,закріплено в законі України «Про безоплатну правову допомогу», згідно якому держава гарантує особам відновлення їх прав у випадку їх порушення, діями чи бездіяльністю органів державної влади, органів місцевого самоврядування, посадових і службових осіб.

Ця правова допомога включає такий вид послуги як медіація. А саме, в ст. 7 ч.2 п.2 Закону України «Про безоплатну правову допомогу» [24], зафіксовано що одним із видів послуг з надання первинної безоплатної правової допомоги в Україні $є$ надання допомоги в забезпеченні доступу особи до вторинної правової допомоги та медіації. 
Механізм реалізації медіації також закладений в законі України «Про соціальні послуги», в частині реалізації прав осіб, на отримання допомоги у складних життєвих обставинах (ст.16 ч.2 п.),медіація включена як базова соціальна послуга [30].

Крім того, наказом Міністерства соціальної політики України від 17 серпня 2016 року № 892 затверджено «Державний стандарт соціальної послуги посередництва (медіації)», що визначає зміст, обсяги, умови та порядок надання соціальної послуги посередництва (медіації), показники іiі якості для суб'єктів різних форм власності та господарювання, які надають таку послугу.

Основні заходи, що становлять зміст соціальної послуги посередництва (медіації), форми роботи та орієнтовний час для їх виконання, передбачають: допомогу у врегулюванні конфліктів; ведення переговорів; опрацювання шляхів та умов розв'язання конфлікту [26].

Те що органи державної влади самі відчувають необхідність у спілкуванні з суб'єктами господарювання під час виконання своїх службових обов'язків, свідчать законодавчо визначені процедури консультування [15, с. 122-123].

На пошук нових форм взаємодії між органами державної влади та місцевого самоврядування, бізнес-структурами та представниками громадянського суспільства спрямована Національна стратегія сприяння розвитку громадянського суспільства в Україні на 20162020 роки [31].

Принцип взаємної поваги та пошуку компромісних рішень закладений в основу закону України «Про соціальний діалог в Україні» (ст. 3) [29].

Все це вказує на перегляд сутності державного управління, перезавантаження змісту відносин на рівні «держава - громадянин» $[8$, c. 31].

Таким чином, зміна ролі держави і характеру іiі взаємодії 3 громадянами, процеси реформування що відбуваються вимагають зміну підходах до вирішення спорів за участю органів державної влади, в тому числі застосування медіації як способу врегулювання конфлікту (спору) шляхом переговорів. 
Досвід європейських держав у цій сфері, доводить, що запровадження альтернативних методів урегулювання спорів $\epsilon$ найефективнішою передумовою вирішення правових конфліктів та спорів.

3 огляду на те, що фундаментальним принципом права $\mathrm{CC} \in$ принцип доступу до правосуддя, для того щоб забезпечити кращий доступ до правосуддя Рада СС закликала держави - члени сприяти та створювати альтернативні методи вирішення спорів, зокрема медіацію.

I як наслідок ратифікація Україною у 2014 році Угоди про асоціацію з Свропейським Союзом [28] остаточно зняла сумніви щодо інтеграційних пріоритетів i вектора руху нашої країни до набуття повноправного членства в Свропейському Союзі та закріпила пріоритетність запровадження альтернативних позасудових процедур, серед яких медіація $є$ основним методом врегулювання спорів [27; 37; 36].

Також, Україна 7 серпня 2019 року приєдналася до Конвенції ООН «Про міжнародні угоди за результатами медіації», що додає правничій медіації гарантії виконання угод і $є$ тією частинкою «пазла» ефективної та уніфікованої процедури реалізації угод, укладених унаслідок медіації, якої раніше не вистачало [41].

В. Мотиль, вважає що законодавство СС не є обов'язковим для України, але 3 огляду на досягнення кінцевої мети європейської інтеграції, а саме набуття повноправного членства в Свропейському Союзі, Україні доцільно імплементувати також і положення цих правових актів у національне законодавство [19, с. 48].

Поширеною практикою СС є використання альтернативних методів вирішення спорів між адміністративними органами й зацікавленими сторонами. Це прописано в Рекомендаціях $\operatorname{Rec}(2001)$ 9 Комітету Міністрів Ради Свропи щодо альтернатив судовому розгляду спорів між адміністративними органами й сторонами приватними особами від 5 вересня 2001 року, наголошено на перевагах використання альтернативних засобів розгляду спорів та рекомендовано урядам держав - членів сприяти використанню альтернативних засобів [33]. 
Очевидно, що медіація на просторах Європейського союзу $\epsilon$ одним із визнаних та ефективних інструментів комунікації (спілкування), який приносить видимі результати у процесі врегулювання конфлікту (спору) або кризи.

Національне законодавство України має підгрунтя для застосування медіації поряд 3 іншими методами врегулювання i вирішення правових спорів в системі органів державного управляння, але є фактори які стримують їі застосування.

Загалом стримувальним фактором застосування медіації, як способу вирішення публічно-правових спорів полягає у відсутності повноважень у суб'єкта владних повноважень щодо проведення процедури медіації.

3. Красилівська пояснює цю ситуацію психологічними (боязнь посадової особи відповідальності за самостійно прийняте рішення) та юридичними («заборонено все, крім того, що прямо дозволено») факторами [16, с. 142].

В той же час в нормативно-правових засадах діяльності державного службовця закладені дискреційні повноваження, які дозволяють ці фактори подолати.

Термін «дискреційні» discretionnaire (франц.) має французьке походження, яке означає залежність від особистого розсуду, або discretio (лат.) - рішення посадової особи або державного органу, віднесеного до їх компетенції питання на власний розсуд в порядку реалізації дискреційної влади $[9$, с. 16].

При цьому ключовим є те, що межі поведінки (розсуду) суб'єкта владних повноважень окреслені в законодавчих актах, і відступ від цих вимог призведе до порушення права та охоронюваних законом інтересів особи. Такий висновок можна зробити з рішення Конституційного Суду України від 8 червня 2016 року (№ 3-рп/2016) [36].

Дискреційні повноваження та адміністративний розсуд у руках державного службовця мають стати тим важелем, за допомогою якого будуть налагоджуватися зв'язки держави та громадянського суспільства. Цей державний службовець повинен бути втіленням довіри народу до влади, тобто потрібна трансформація не тільки 
правового статусу, а й самої правосвідомості службовця [6, с. 135$136]$.

На думку А. Бортнікової, наявна законодавча варіативність у повноваженнях державного службовця $є$ сприятливим чинником для застосування медіації, оскільки можливість вибору того чи іншого варіанту рішення сприяе досягненню компромісу, більш якісному врахуванню і об'єктивних обставин, і суб'єктивних точок зору сторін [5].

Як бачимо, законодавством України передбачено використання медіації, як способу вирішення публічно-правових спорів шляхом самостійного узгодження та прийняття компромісних (вигідних) рішень між усіма зацікавленими сторонами.

Але для того, щоб медіація набула статусу правового інституту необхідна наявність взаємопов'язаних між собою правових норм, що регулюють відносини у сфері медіаційної діяльності. При цьому така система норм повинна забезпечити баланс інтересів усіх учасників правовідносин, виховувати правосвідомість i взаємоповагу в суспільстві.

Саме тому, зараз на розгляді у Верховній Раді України знаходиться проект закону «Про медіацію» № 3504 від 19 травня 2020 року, цим проектом пропонується запровадити інститут медіації на законодавчому рівні та визначити правові засади та порядок проведення медіації в Україні [32].

Очевидно, що окрім загального / рамкового закону про медіацію необхідно прописати конкретні правила щодо медіації в законодавстві, що регулює публічно-адміністративну сферу. Причини загальновідомі. Успішне застосування будь-якого методу альтернативного вирішення спору можливо лише в тому випадку, коли адміністративний орган готовий змінити спосіб застосування конкретного повноваження в кожному подібному випадку в майбутньому, а отже, готовий змінювати свої підходи за наявності законних та об'єктивних причин» [2, с. 62].

Прийняття цього спеціального закону буде мати позитивний ефект на розвиток інституту медіації в Україні. Але для цього потрібно не лише прийняття спеціального закону, а й комплексний 
підхід до внесення змін у національне законодавствощодо організації інституту медіації, який відповідатиме як громадським, так і державним інтересам.

Не останнє місце в цьому питанні займає професійна компетентність державних службовців у сфері побудови конструктивних міжособистісних і соціальних стосунків. Адже саме від таких якостей як вміння вести переговори, обгрунтовувати свої позиції, знаходити компромісні рішення; уміння проводити обговорення, збалансовуючи різні позиції, погляди, точки зору залежить належне урядування.

Тому імплементація медіаційних технік у професійну діяльність державних службовців закріпилобцюнорму та далоб змогу використовувати їх під час урегулювання конфліктів, що виникають у системі державного управління.

На потенціал і цінність цього інструментарію вказує О. Лук'яновська, «інформованість про принципи і технології медіації може істотно вплинути на зміну світогляду державного службовця у відносинах із громадянами та одне 3 одним, що розширить можливості вирішення спорів прозорим, некорумпованим способом» [18, с. 38].

Крім того, сучасний стан розвитку держави базується на концепції сервісної держави, яка передбачає координацію зв'язків знизу до верху, між усіма верствами населення, де одним з головних факторів сервісного підходу є реалізація врегулювання конфліктів шляхом процедури медіації спорів.

Звісно, медіація не є ліками від усіх проблем (конфліктів) проте вона $\epsilon$ ефективним превентивнім засобом запобігання і вирішення правових спорів в системі державного управління та може стати тим фундаментом, що започаткує новий рівень взаємовідносин держави 3 громадянським суспільством. Але як кажуть китайці, «щоб сидіти під деревом, його треба спочатку виростити».

Висновки. В цілому держава усвідомлює роль медіації у вирішенні соціально значущих завдань. Суттю медіації як соціального явища, є те що цей метод орієнтований на розв'язання спорів у позасудовому порядку, на досягнення консенсусу, згоди 
різних суперечливих поглядів, позицій, вирішення спірних ситуацій. Позитивним є той факт, що цей інструмент, як альтернативний спосіб превентивної профілактики запобігання спорам (конфліктам), шляхом врахування інтересів кожної сторони та досягненням компромісного рішення є затребуванимвсуспільстві.

В контексті забезпечення реалізації принципів верховенства права та доступу до правосуддя держава повинна забезпечити доступ до альтернативних методів вирішення правових спорів. Серед яких чільне місце набула медіація.

Аналіз законодавства показує, що на шляху запровадження практики медіації вже зроблено чималі кроки, але цього недостатньо. Необхідно прийняти спеціальний закон про медіацію, та внести зміни до законодавства.

Прийняття закону сприятиме професійної організації та введення в широку практику на всіх рівнях влади та громадянського суспільства інституту медіації,яке стане додатковим механізмом вирішення спорів, налагодження комунікації та пошуку компромісних і спільно вироблених консенсусних рішень між органами влади і суспільством.

Використання медіації в системі державного управління дозволить: узгодити інтереси та дотриматися балансу інтересів у будь-якій сфері суспільних відносин; посилить організаційний потенціал суб'єктів управління; зміцніть координацію дій i зближення стратегій наявних інститутів державної влади та управління; підвищить соціальну стабільність в суспільстві та знизять конфліктогенність в соціуме; забезпечить збалансованість державно-управлінських відносин тощо.

Якщо говорити про перспективи подальших розвідок, то на наш погляд вони повинні стосуватися вивчення можливостей застосування медіації в самих різних сферах діяльностіі суспільного життя, в тому числі вивчення можливостей застосування медіації як альтернативного способу запобігання спорам (конфліктам) в процесах владно-управлінської діяльності.

\section{Стаття надійшла до редакції: 12.06.21}




\section{MEDIATION AS A METHOD FOR PREVENTING CONFLICTS} IN THE SPHERE OF PUBLIC ADMINISTRATION

Volodimer Voloshyn, $\mathrm{PhD}$ in Public Administration, head of department of organizational and administrative support of the Center for evaluation of candidates for civil service positions Ukrainian School of Government, Kyiv, Ukraine.

Mustafayeva Urie S., $\mathrm{PhD}$ in Public Administration, head of department of testology and experte valuationo of the Center for evaluation of candidates for civil service positions Ukrainian School of Government, Kyiv, Ukraine.

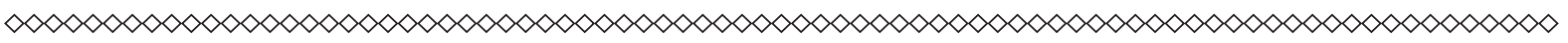

The article presents an analysis of the social and legal nature of mediation and the possibilities of mediation as a way to prevent and resolve disputes (conflicts) in the public administration system. It is proved that the Ukrainian state is aware of the role of mediation in solving socially significant problems. The essence of mediation as a social phenomenon is that this method is focused on resolving disputes out of court, reaching consensus, agreeing to various conflicting views, positions, and resolving controversial situations. It is a positive fact that this tool, as an alternative way of preventive prevention to prevent disputes (conflicts), by taking into account the interests of each party and reaching a compromise solution, is in demand in society.

The analysis of the legislation showed that considerable steps have already been taken on the path of introducing the practice of mediation, but this is not enough. It is necessary to adopt a special law on mediation, and amend the legislation. The adoption of the law will contribute to the professional organization and the introduction into wide practice at all levels of government and civil society of the institution of mediation, which will become an additional mechanism for resolving disputes, establishing communication and finding compromise and jointly produced consensus decisions between the authorities and society. 
The use of mediation in the public administration system will allow: to harmonize interests and maintain a balance of interests in any area of public relations; will strengthen the organizational potential of the subjects of management; strengthen coordination of actions and convergence of strategies of existing institutions of government and administration; will increase social stability in society and reduce conflict potential in society; will ensure the balance of state-management relations and the like.

If we talk about the prospects for further research, then, in our opinion, they should relate to the study of the possibilities of using mediation in various fields of activity and public life, including the study of the possibilities of using mediation as an alternative way to prevent disputes (conflicts) in the processes of power and management activities. servant.

Key words: public administration, conflict, mediation, civil

\section{Received: 15.06.21}

\section{References}

1. Belinska, O.V. (2011). Mediatsiia - alternatyvne vyrishennia sporiv [Mediation - alternative dispute resolution]. Visnyk Vyshchoi rady yustytsii Bulletin of the High Council of Justice, 1 (5), (pp. 158 -173) [in Ukrainian].

2. Bert Maan. (2020). Gap-Analiz vprovadzhennia instytutu mediatsii v Ukraini [Gap-Analysis of the implementation of the institute of mediation in Ukraine] [in Ukrainian].

3. Borodin, Ye. (2019). Orhanizatsiino-pravovi pidstavy zastosuvannia mediatsii v systemi derzhavnoho upravlinnia [Organizational and legal grounds for the use of mediation in public administration]. Aspekty publichnoho upravlinnia - Aspects of public administration, (Vols. 7), 4, (pp. 25-34). Retrieved from http://nbuv.gov.ua/UJRN/aplup_2019_7_4_5 [in Ukrainian].

4. Bortnikova, A.H. (2018). Novevyznachennia poniattia «publichnopravovoho sporu» u svitli chynnosti novoi redaktsii KAS Ukrainy [New definition of "public-legal dispute" in the light of the new edition of the CAS of Ukraine]. «Suchasni pravovi systemy svitu: tendentsii ta faktory rozvytku»- 
«Modern legal systems of the world: trends and factors of development», (pp. 74-77) [in Ukrainian].

5. Bortnikova, A.H. (2017). Pravovi zasady zastosuvannia mediatsii yak sposobu vyrishennia publichno-pravovykh sporiv [Legal principles of mediation as a way of resolving public-law disputes]. Aktualni problemy vitchyznianoi yurysprudentsii - Actual problems of domestic jurisprudence, (Vols. 2), 6, (pp. 77 - 80) [in Ukrainian].

6. Bortnikova, A.H. (2017). Shchodo dyskretsiinykh povnovazhen subiekta vladnykh povnovazhen v umovakh ukrainskoi pravovoi diisnosti [On the discretionary powers of the subject of power in the conditions of Ukrainian legal reality]. (pp. 133-136). Poland: Sandomierz [in Ukrainian].

7. Hirnyk, A.M. (2010). Osnovy konfliktolohii [Fundamentals of conflictology]. Kyiv: Vyd. dim «Kyievo-Mohylianska akademiia» [in Ukrainian].

8. Dzhafarova, M.V. (2017). Subiekt vladnykh povnovazhen: teoretychni ta prykladni problemy vyznachennia [The subject of power: theoretical and applied problems of definition]. Naukovyi visnyk Khersonskoho derzhavnoho universytetu. Seriia Yurydychni nauky - Scientific Bulletin of Kherson State University. Legal Sciences Series, (Vols. 2), 1, (pp. 30-33) [in Ukrainian].

9. Dyskretsiini povnovazhennia subiektiv vlady: svoboda rozsuduchy shliakh do svavillia chynovnykiv? [Discretionary powers of subjects of power: freedom to judge the way to arbitrariness of officials?]. (n.d.). ppt-online.org. Retrieved from http://ppt-online.org/77468 [in Ukrainian].

10. Kalinina, E.V. (2016). Otdelnyie aspektyi primeneniya mediativnyih tehnologiy pri razreshenii pravovyih konfliktov [Certain aspects of the use of media technologies in resolving legal conflicts]. Teoriya i praktika obschestvennogo razvitiya - Theory and practice of social development, 12, (pp. 114 - 116) [in Russian].

11. Kafarskyi, V.V. (2014). Mediatsiia v administratyvnomu sudochynstvi [Mediation in administrative proceedings]. Prykarpatskyi yurydychnyi visnykPrykarpattya Legal Bulletin, 3 (6), (pp. 152-165) [in Ukrainian].

12. Kyrii, S.L. (2014). Orhanizatsiinyi konflikt u publichnomu upravlinni yak indykator neobkhidnosti zmin [Organizational conflict in public administration as an indicator of the need for change]. Derzhavne budivnytstvo - State Construction, 2. Retrieved from http://nbuv.gov.ua/UJRN/DeBu_2014_2_4 [in Ukrainian]. 
13. Kozlov, K.I. (2010). Politychna modernizatsiia: implementatsiia pryntsypiv Good Governance [Political modernization: implementation of the principles of Good Governance]. Teoriia ta praktyka derzhavnoho upravlinnia - Theory and practice of public administration, 4, (pp. 135-140). Retrieved from http://nbuv.gov.ua/j-pdf/Tpdu_2010_4_22.pdf [in Ukrainian].

14. Konstytutsiia Ukrainy: pryiniata na piatii sesii Verkhovnoi Rady Ukrainy 28 chervnia $1996 \mathrm{r}$. [The Constitution of Ukraine: adopted at the fifth session of the Verkhovna Rada of Ukraine on June 28, 1996]. (n.d.). zakon. rada.gov.ua. Retrieved from https://zakon.rada.gov.ua/laws/show/254k/96-vr [in Ukrainian].

15. Krasilovska, Z.V. (2017). Stanovlennia instytutu mediatsii v systemi publichnoho upravlinnia: teoretyko-pravovyi aspekt [Formation of the institute of mediation in the system of public administration: theoretical and legal aspect]. Candidate's thesis. Odessa: Odessa Regional Institute of Public Administration [in Ukrainian].

16. Krasilovska, Z.V. (2017). Stanovlennia instytutu mediatsii v systemi publichnoho upravlinnia: teoretyko-pravovyi aspekt [Formation of the institute of mediation in the system of public administration: theoretical and legal aspect]. Extended abstact of candidate's thesis. Odessa: Odessa Regional Institute of Public Administration [in Ukrainian].

17. Lukyanovskaya, O.V. (2018). O vozmozhnosti primeneniya protseduryi mediatsii pri razreshenii konfliktov na gosudarstvennoy grazhdanskoy sluzhbe [On the possibility of using the mediation procedure when resolving conflicts in the civil service]. Vestnik SGYuA - Bulletin of SGLA, 1 (120), (pp. 34-38) [in Russian].

18. Motyl,V.I.(2014). Stantaperspektyvypravovohorehuliuvanniamediatsii $\mathrm{v}$ Ukraini [Status and prospects of legal regulation of mediation in Ukraine]. Yurydychna Ukraina - Legal Ukraine, 11, (pp. 46-52) [in Ukrainian].

19. Nyzhnyk, N.R., \& Tsvietkov, V.V (1998). Pryroda ta zmist administratyvnoi reformy v Ukraini [The nature and content of administrative reform in Ukraine]. Reformuvannia derzhavnoho upravlinnia $v$ Ukraini: problemy i perspektyvy - Public administration reform in Ukraine: problems and prospects. Kyiv: Oriiany [in Ukrainian].

20. Osadchyi, A.Yu. (2013). Yurysdyktsiia sudiv z rozghliad u publichnopravovykh sporiv [Jurisdiction of courts for consideration in public law disputes]. Yurydychnyi visnyk - Legal Bulletin, 3, (pp. 101-106) [in Ukrainian]. 
21. Polishchuk, M.Ya. (2014). Poniattia mediatsii yak alternatyvnoho metodu vyrishennia sporiv [The concept of mediation as an alternative method of dispute resolution]. Derzhavo i pravo. Yurydychni i politychni nauky - State and Law. Legal and political sciences, 65, (pp. 134-139) [in Ukrainian].

22. Prytyka, Yu.D. (2006). Teoretychni problemy zakhystu prav uchasnykiv tsyvilnykh pravovidnosyn $\mathrm{v}$ treteiskomu sudi [Theoretical problems of protection of the rights of participants of civil legal relations in the arbitration court]. Doctor's thesis. Kyiv: KNU of Tarasa Shevchenka [in Ukrainian].

23. Zakon Ukrainy Pro bezoplatnu pravovu dopomohu vid 2 chervnia 2011 roku No 3460-VI [Law of Ukraine On free legal aid of June 2, 2011 No 3460VI]. (n.d.). zakon.rada.gov.ua. Retrieved from https://zakon.rada.gov.ua/laws/ show/3460-17\#Text [in Ukrainian].

24. Zakon Ukrainy Pro dostup do sudovykh rishen vid 22 hrudnia 2005 roku No 3262-IV, potochna redaktsiia redaktsiia vid 23 kvitnia 2021 roku [Law of Ukraine On access to court decisions of December 22, 2005 No 3262-IV, current version of April 23, 2021]. (n.d.). zakon5.rada.gov.ua. Retrieved from http://zakon5.rada.gov.ua/laws/show/3262-15 [in Ukrainian].

25. Nakaz Ministerstva sotsialnoi polityky Ukrainy Pro zatverdzhennia Derzhavnoho standartu sotsialnoi posluhy poserednytstva (mediatsii) vid 17.08.2016 No 892 [Order of the Ministry of Social Policy of Ukraine On approval of the State standard of social mediation service: dated 17.08.2016 No 892]. (n.d.). zakon.rada.gov.ua. Retrieved from https://zakon.rada.gov.ua/laws/ show/z1243-16\#Text [in Ukrainian].

26. Postanova Verkhovnoi Rady Ukrainy Pro Zaiavu Verkhovnoi Rady Ukrainy «Pro yevropeiskyi vybir Ukrainy» vid 16 veresnia 2014 r. [Resolution of the Verkhovna Rada of Ukraine On the Statement of the Verkhovna Rada of Ukraine «On the European Choice of Ukraine» of September 16, 2014]. (n.d.). zakon5.rada.gov.ua. http://zakon5.rada.gov.ua/laws/show/ru/1679-1 [in Ukrainian].

27. Zakon Ukrainy Pro ratyfikatsiiu Uhody pro asotsiatsiiu mizh Ukrainoiu, z odniiei storony, ta Yevropeiskym Soiuzom, Yevropeiskym spivtovarystvom $\mathrm{z}$ atomnoi enerhii i yikhnimy derzhavamy-chlenamy, $\mathrm{z}$ inshoi storony vid 16 veresnia 2014 r. [Law of Ukraine On ratification of the Association Agreement between Ukraine, on the one hand, and the European Union, the European Atomic Energy Community and their Member States, on the other hand of 16 
September 2014]. (n.d.). zakon2.rada.gov.ua. Retrieved from http://zakon2. rada.gov.ua/laws/show/1678-18 [in Ukrainian].

28. Zakon Ukrainy Pro sotsialnyi dialoh v Ukraini vid 23 hrudnia 2010 roku No 2862-VI, potochna redaktsiia pryiniattia vid 23 hrudnia 2010 roku [Law of Ukraine On social dialogue in Ukraine of December 23, 2010 No 2862-VI, current version of adoption of December 23, 2010]. (n.d.). zakon.rada.gov.ua. Retrieved from https://zakon.rada.gov.ua/laws/show/2862-17\#Text [in Ukrainian].

29. Zakon Ukrainy Pro sotsialni posluhy vid 17 sichnia 2019 roku No 2671-VIII [Law of Ukraine On social services of January 17, 2019 No 2671VIII]. (n.d.). zakon.rada.gov.ua. Retrieved from https://zakon.rada.gov.ua/ laws/show/2671-19\#Text [in Ukrainian].

30. Ukaz Prezydenta Ukrainy Pro spryiannia rozvytku hromadianskoho suspilstva v Ukraini: vid 26 liutoho 2016 roku No 68/2016 [On promoting the development of civil society in Ukraine: Decree of the President of Ukraine of February 26, 2016 No 68/2016. (n.d.). zakon.rada.gov.ua. Retrieved from https://zakon.rada.gov.ua/laws/show/68/2016\#n25 [in Ukrainian].

31. Proekt zakonu Ukrainy «Pro mediatsiiu» reiestr. No 3504 vid 19.05.2015 roku [Draft Law of Ukraine «On Mediation» register. No 3504 dated 19.05.2015]. (n.d.). search.ligazakon.ua. Retrieved from http://search. ligazakon.ua/1_doc2.nsf/link1/JI02134A.html [in Ukrainian].

32. Rekomendatsiia Rec 9 Komitetu Ministriv Rady Yevropy derzhavam-chlenam shchodo alternatyv sudovomu rozghliadu sporiv mizh administratyvnymy orhanamy y storonamy pryvatnymy osobamy. Ukhvaleno Komitetom Ministriv Rady Yevropy na 762 zasidanni zastupnykiv ministriv 5 veresnia 2001 roku [Recommendation Rec 9 of the Committee of Ministers of the Council of Europe to member states on alternatives to litigation between administrative authorities and private parties. Approved by the Committee of Ministers of the Council of Europe at the 762nd meeting of the Ministers' Deputies on 5 September 2001]. (2001). (n.d.). www.scourt.gov.ua. Retrieved from http://www.scourt.gov.ua/clients/vsu/vsu.nsf.pdf [in Ukrainian].

33. Rieznikov, V.V. (2012). Mediatsiia (poserednytstvo) yak sposib vyrishennia hospodarskykh spori [Mediation (mediation) as a way to resolve economic disputes]. Visnyk Kyivskoho natsionalnoho universytetu imeni Tarasa Shevchenka. Yurydychni nauky - Bulletin of the Taras Shevchenko National University of Kyiv. Legal sciences, 90, (pp. 10-15) [in Ukrainian]. 
34. Rishennia Konstytutsiinoho Sudu Ukrainy vid 8 chervnia 2016 roku (No 3-rp/2016) // [Judgment of the Constitutional Court of Ukraine of 8 June 2016 (No 3-rp/2016)]. (n.d.). ccu.gov.ua. Retrieved from https://ccu.gov.ua/ sites/default/files/ndf/3-rp2016.pdf [in Ukrainian].

35. Rukovodstvo Mezhdunarodnogo instituta po predotvrascheniyu i razresheniyu konfliktov (CPR) po mediatsii i ARS v Evrope [Guidelines of the International Institute for Conflict Prevention and Resolution (CPR) on Mediation and ADR in Europe]. (2015). (n.d.). www.cpradrorg. Retrieved from https://www.cpradr.org/resource-center/non-english-language-resources/ russian/-CPR [in Russian].

36. Uroda pro asotsiatsiiu Ukrainy z Yevropeiskym Soiuzom [Government on the association of Ukraine with the European Union]. (n.d.). zakon.rada. gov.ua. Retrieved from https://zakon.rada.gov.ua/laws/show/984_011\#Text [in Ukrainian].

37. Khliborob, N.Ye. (2012). Publichno-pravovyi spir yak predmet yurysdyktsiinoi diialnosti administratyvnoho sudu [Public law dispute as a subject of jurisdictional activity of the administrative court]. Candidate's thesis. Lviv: National University «Lviv Polytechnic» [in Ukrainian].

38. Hudoykina, T.V. (2015). Mirovoe soglashenie kak primiritelnaya protsedura razresheniya yuridicheskogo spora i konflikta [Settlement agreement as a conciliatory procedure for resolving a legal dispute and conflict]. Vestnik Vladimirskogo gosudarstvennogo universiteta imeni Aleksandra Grigorevicha i Nikolaya Grigorevicha Stoletovyih. Seriya: Yuridicheskie nauki-Bulletin of the Vladimir State University named after Alexander Grigorievich and Nikolai Grigorievich Stoletov. Series: Legal Sciences, 1(3), (pp. 70-77) [in Russian].

39. Shumova, K.A. (2015). Printsipyi mediatsii [Principles of mediation]. Candidate's thesis. Saratov [in Russian].

40. Reznikov, A., Potemkin, Y., \& Bezhlebnaya, N. Ukraina pidpysala Sinhapursku konventsiiu, shcho sproshchuie vykonannia mizhnarodnykh uhod, ukladenykh za rezultatamy mediatsii [Ukraine has signed the Singapore Convention, which simplifies the implementation of international agreements concluded as a result of mediation]. www.lexology.com. Retreived from https:// www.lexology.com/library/detail. aspx?g=5e9f2fb3 [in Ukrainian].

41. Shtyrev, O. \& Tymofeev S. (2020). The phenomenon of professional burn-out of civil servants (the case study of the executive authorities of the 
Mykolaiv region). Presented at the Scientific and practical international conference: Public Administration in the 21st Century: Problems and Development Prospects, National University of Civil Defence of Ukraine, Kharkiv: Zenodo. http://doi.org/10.5281/zenodo.4277912 [in Ukrainian].

\section{Відомості про авторів / Information about the Authors}

Волошин Володимир Геннадійович: Центр оцінювання кандидатів на зайняття посад державної служби, Українська школа урядування, вул. Прорізна, 15 м. Київ, 01034, Україна.

Volodimer Voloshyn: Center for evaluation of candidates for civil service positions Ukrainian School of Government, 15, Prorizna str., Kiev, 01034, Ukraine.

\section{ORCID. ORG./ 0000-0002-7475-3553}

\section{E-mail: voloshinv@meta.ua}

Мустафаєва Уріє С.: Центр оцінювання кандидатів на зайняття посад державної служби, Українська школа урядування, вул. Прорізна, 15 м. Київ, 01034, Україна.

Mustafayeva Urie S., Center for evaluation of candidates for civil service positions Ukrainian School of Government, 15, Prorizna str., Kiev, 01034, Ukraine.

ORCID. ORG./ 0000000251284483

\section{E-mail: umustafaeva@usg.org.ua}

